\title{
HUBUNGAN ANTARA KESIAPAN BELAJAR DENGAN PRESTASI BELAJAR SISWA SMK
}

\author{
Hendra Budiman ${ }^{1}$, Aam Hamdani ${ }^{2}$ \\ Universitas Pendidikan Indonesia \\ Jl. Dr. Setiabudhi No. 229 Bandung 40154 \\ budimanhendra0@gmail.com
}

\begin{abstract}
ABSTRAK
Penelitian ini bertujuan untuk memperoleh gambaran umum tentang tingkat kesiapan belajar siswa, tingkat pencapaian prestasi belajar siswa serta untuk menguji apakah terdapat hubungan antara kesiapan belajar dengan prestasi belajar siswa pada mata pelajaran merawat sistem bahan bakar konvensional kendaraan ringan. Penelitian ini digunakan metode ex post facto dengan teknik pengumpulan data berupa teknik angket untuk kesiapan belajar siswa dan dokumentasi untuk prestasi belajar siswa kelas XI pada mata pelajaran Merawat Sistem Bahan Bakar Konvensional Kendaraan Ringan di SMKN 6 Bandung. Analisa data yang dipakai menggunakan statistik parametrik. Berdasarkan hasil penelitian yang telah dilaksanakan didapat tingkat kesiapan belajar siswa dalam kategori baik (81,11\%), tingkat pencapaian prestasi belajar siswa kelas XI dalam kategori baik (72,08\%), dan hubungan antara kesiapan belajar dengan prestasi belajar siswa memiliki tingkat korelasi yang cukup tinggi $\left(\mathrm{r}_{\mathrm{xy}} 0,53\right)$. Pengujian hipotesis dalam penelitian ini ialah terdapat hubungan yang positif dan signifikan antara kesiapan belajar dengan prestasi belajar siswa pada mata pelajaran merawat sistem bahan bakar konvensional kendaraan ringan. Implikasi dari penelitian ini hendaknya guru sebelum memulai mata pelajaran merawat sistem bahan bakar konvensional kendaraan ringan bisa mengetahui dan meningkatkan faktor kesiapan belajar siswa.
\end{abstract}

Kata kunci: kesiapan belajar, sistem bahan bakar, kendaraan ringan

\section{PENDAHULUAN}

Kesiapan belajar adalah kemauan yang timbul dari pribadi individu untuk berkembang dan terjadi melalui proses waktu (memerlukan waktu yang cukup lama untuk mencapainya). Kesiapan diri siswa sangatlah penting untuk meraih keberhasilan dalam kegiatan belajar (Mulyani, 2013). Kesiapan adalah semua kondisi individu yang membuatnya siap untuk memberikan respon atau jawaban didalam acara tertentu terhadap suatu situasi (Slameto, 2003). Belajar merupakan serangkaian kegiatan jiwa raga untuk memperoleh suatu perubahan tingkah laku sebagai hasil dari pengalaman individu dalam interaksi dengan lingkunganya yang menyangkut kognitif, afektif, dan psikmotor (Djamarah, 2011). Belajar adalah suatu proses perubahan perilaku atau pribadi seseorang berdasarkan praktik atau pengalaman tertentu. Kesiapan belajar adalah kondisi-kondisi yang mendahului kegiatan belajar itu sendiri. Tanpa kesiapan atau kesediaan ini, proses belajar tidak akan terjadi. Pra kondisi belajar itu terdiri atas perhatian, motovasi, dan perkembangan kesiapan. Kesiapan belajar adalah semua kondisi individu yang membuatnya siap untuk memberinya respon atau jawaban didalam acara tertentu terhadap

\footnotetext{
${ }^{1}$ Mahasiswa Departemen Pendidikan Teknik Mesin FPTK, UPI

${ }^{2}$ Dosen Departemen Pendidikan Teknik Mesin FPTK, UPI
} 
suatu situasi. Motivasi berasal dari bahasa latin movere yang bermakna bergerak, istilah ini bermakna mendorong mengarahkan tingkah laku manusia (Iskandar, 2009). Perkembangan disini sebagai perubahan-perubahan yang dialami oleh individu atau organisme menuju tingkat kedewasaannya (maturity) yang berlangsung secara sistematik, progresif, dan berkeseimbangan, baik mengenai fisik, maupun psikis. Keseluruhan semua kondisi individu yang membuatnya siap untuk memberinya respon atau jawaban didalam acara tertentu terhadap suatu situasi. Prestasi belajar merupakan indikator dari perubahan dan perkembangan perilaku dalam teori kognitif (penalaran), efektif (penghayatan), dan konatif (keterampilan) (Syah, 2010). Prestasi belajar merupakan segala perilaku yang dimiliki siswa sebagai akibat dari proses belajar yang ditempuhnya. Melalui semua akibat dari proses belajar yang berlangsung di sekolah maupun di luar sekolah yang bersifat kognitif, afektif, maupun psikomotor yang sengaja maupun tidak disengaja. Belajar merupakan hal yang sangat kompleks. Apabila ini dikaitkan dengan hasil belajar siswa, ada beberapa faktor yang mempengaruhi prestasi belajar. Faktor-faktor yang mempengaruhi prestasi belajar (Mayasari, et. al., 2013) adalah faktor internal, yaitu faktor yang timbul dari dalam diri siswa itu sendiri, sifatnya: psikologi, seperti: integensi, kemauan, bakat, minat, sikap dan perhatian dan faktor eksternal, yaitu faktor yang timbul dari luar diri siswa, diantaranya lingkungan, lingkungan keluarga, lingkungan masyarakat.

Kesiapan belajar siswa berkaitan erat dengan perolehan prestasi belajarnya, mencapai kemajuan studi, dan akan mengsukseskan belajar disekolahnya. Penjelasan di atas menyatakan bahwa kesiapan belajar merupakan salah satu faktor yang dapat mempengaruhi prestasi belajar siswa yang akan dicapai. Kesiapan belajar adalah kondisikondisi yang mendahului kegiatan belajar itu sendiri. Ada hubungan antara kesiapan belajar dengan pestasi belajar apabila siswa memiliki kesiapan belajar yang baik, efektif dan efesien, maka prestasi belajarnya tinggi, sedangkan apabila siswa tersebut tidak memiliki kesiapan belajar yang baik.

\section{METODE PENELITIAN}

Metode yang digunakan dalam penelitian ini adalah metode penelitaian bentuk ex post facto. Variabel bebas dalam penelitian ini yaitu kesiapan belajar siswa dengan mata pelajaran merawat sistem bahan bakar kendaraan ringan. Variabel terikatnya adalah prestasi siswa yang dituangkan dalam bentuk nilai. Populasi dipenelitian ini adalah seluruh jumlah siswa kelas XI TKR 4 dan XI TKR 5 SMKN 6 Bandung yang berjumlah 67 siswa. 
Sampel dari penelitian ini sebanyak 67 orang siswa sesuai dengan jumlah populasi. Instrumen yang digunakan adalah angket dan dokumentasi.

\section{HASIL PENELITIAN}

Kesiapan belajar siswa terkosentrasi sangat baik sebesar 9 responden, baik 10 responden, cukup baik 25 responden, kurang baik sebanyak 15 responden, sangat rendah sebanyak 8 responden. Besarnya persentase perhatian adalah $80,78 \%$ motivasi sebesar $84,29 \%$ serta perkembangan kesiapan $74,63 \%$, kesiapan belajar siswa pada mata pelajaran merawat sistem bahan bakar konvensional kendaraan ringan di SMKN 6 Bandung tahun ajaran 2016/2017 berada pada kategori baik dengan tingkat persentase 81,11\%.

Prestasi belajar siswa sangat tinggi sebesar 8 responden, tinggi sebanyak 13 responden, cukup sebanyak 23 responden, kurang sebanyak 14 responden, rendah sebnyak 9 responden. Kesimpulanya berdasarkan hasil uji kecenderungan di atas dilihat dari kireteria kecenderungan dinyatakan bahwa bervariasi. Persentase tingkat pencapaian prestasi belajar siswa dengan persentase $72,08 \%$. dapat dikatagorikan baik kategori baik artinya prestasi siswa sudah sesuai dengan yang diharapkan.

\section{PEMBAHASAN}

Kesiapan belajar dipengaruhi 3 aspek yaitu aspek perhatian terhadap hasil belajar siswa yaitu $80,78 \%$. Atinya perhatian pada kategori baik, besarnya aspek motivasi yaitu kategori sangat baik. Sedangkan besarnya aspek perkembangan kesiapan yaitu 74,63\% artinya perkembangan kesiapan pada kategori baik. Sehingga besar total persentase pengaruh kesiapan belajar terhadap prestasi belajar yaitu 81,11\%. Artinya kesiapan belajar terhadap prestasi pada kategori sangat baik. Tingkat pencapaian prestasi belajar siswa pada mata pelajaran merawat sistem bahan bakar konvensional kendaraan ringan berada pada tingkat persentase $72,08 \%$ dikategorikan baik. Kemudian terdapat hubungan yang positif dan signifikan antara kesiapan belajar dengan prestasi belajar siswa dengan koefesien korelasi sebesar 0,529.Artinya berada pada kategori cukup baik.

\section{KESIMPULAN}

Kesimpulan penelitian ini yaitu terdapat hubungan yang signifikan antara kesiapan belajar dengan prestasi belajar siswa SMK. Kesiapan siswa pada mata pelajaran merawat sistem bahan bakar konvensional kendaraan ringan pada kategori baik. Hal tersebut dilihat 
dari berbagai aspek antara lain aspek perhatian, aspek motivasi, dan aspek perkembangan kesiapan. Tingkat pencapaian prestasi belajar siswa pada kategori baik. Hal tersebut dilihat dari nilai hasil ujian tengah semeter yang diperoleh perserta didik setelah mengikuti proses pembelajaran pada mata pelajaran merawat sisitem bahan bakar konvensional kendaraan ringan. Korelasi antara kesiapan belajar siswa pada mata pelajaran merawat sistem bahan bakar konvensional kendaraan ringan pada tingkat yang cukup baik.

\section{REFERENSI}

Djamarah, S. B. (2011). Psikologi Belajar. Jakarta: Rineka Cipta.

Iskandar. (2009). Psikologi Pendidikan. Jakarta: Gaung Persada Press.

Mayasari, S. et.al. (2013). Pengaruh Motivasi Belajar Terhadap Prestasi Belajar. Conaplin Journal: Indonesian Journal of applied Linguistics, hlm 1-9.

Mulyani, D. (2013). Hubungan Kesiapan Belajar Siswa Dengan Prestasi Belajar. Conaplin Journal: Indonesian Journal of applied Linguistics, hlm. 27-31.

Slameto. (2003). Belajar dan Faktor-faktor yang Mempengaruhinya. Jakarta: PT. Rineka Cipta.

Syah, M. (2010). Psikologi Pendidikan. Bandung. PT. Remaja Rosdakarya. 